\title{
Changes in Fat Content in an Experimental Populations of the Common Vole*
}

\author{
Anna KOEODZIEJ-BANACH
}

Kolodziej-Banach A., 1976: Changes in fat content in an experimental population of the common vole. Acta theriol., 21, 18: 255-266 [With 3 Tables \& 1 Fig.].

The fat content of voles Microtus arvalis (P a 11 as, 1779) in an isolated population of this species was examined by means of the ether extraction method. In order to check whether fat as an indicator of the animals' conditions can be used to forecast the development of a population, studies were made of variations in the degree of their fatness in the light of the ecological parameters of this population: variations in population numbers, actual reproduction and mortality. The degree of fatness of the animals varied in successive years. It increased in autumn and winter, and decreased in early spring. The fat condition of the animals changed in a similar way to changes in population numbers, reproduction and mortality over a two-year cycle. Seasonal changes in fatness of these animals were correlated with intensification of reproduction. The fatness of animals caught in live-traps was below the average value for the corresponding group in the population. During discussion of results it is shown that fat deposited in autumn does not, in the ease of bank voles, form an energy basis for thermoregulation, and consequently is not stored material. It may, however, provide evidence of the current condition of the animal and be an indicator of its physiological state at a given moment.

[Dept. Zool. Ecol., Univ. Warsaw, 00-325 Warszawa, Krakowskie Przedmieście 26/28]

\section{INTRODUCTION}

Fat, as the most variable component of an organism, may form an indicator, not only of metabolic, but also population processes ( $\mathrm{S} \mathrm{a} \mathrm{w} \mathrm{i} \mathrm{c} \mathrm{k} \mathrm{a-}$ $\mathrm{Kapusta}, 1968)$. Studies aimed at defining the degree of fatness of animals are useful to breeders for assessing rate of growth and development, nutrition costs and market value of animals (Kry bill, Bitter \& $\mathrm{Hankins}$, 1952; Pears on, 1963). In the case of birds such studies form one of the methods of studying the bioenergetics of moulting, flight and migration (Odum \& Perkinson, 1951; Odum \& $\mathrm{Co}_{\mathrm{O}}$ nnell, 1956; Dolnik, 1960, 1963; Dolnik \& Bljumental, 1964;

* Praca została wykonana $\mathrm{w}$ ramach problemu węzłowego 09.1.7, koordynowanego przez Instytut Ekologii PAN. 
Newton \& Evans, 1966; C zaja-Topińska, 1969). In relation to the ecology of small rodents studies of this kind are made in order to discover the influence exerted on populations by different factors, e.g.: habitat temperature (S e a la n d e r, 1951), food resources of the habitat (Connell after Golley, 1962), population density (H sia-W u-ping \& S u n-Chun g-l u, 1963).

The purpose of the present study was to examine the fatness of an experimental population of the common vole Microtus arvalis (P a llas, 1779) and to ascertain whether fat, as an indicator of the animals' condition, can be used to forecast the development of a given population. This problem may prove of importance in view of the search being made for mechanisms controlling the occurrence of outbreaks of these animals on cultivated fields, and means of foreseeing such outbreaks.

\section{STUDY AREA, METHODS AND MATERIAL}

Material for these studies was collected in experimental populations of the Institute of Ecology, Polish Academy of Sciences, at Dziekanów Leśny near Warsaw. These were two populations $(A$ and $B$ ) of common voles living in a lucerne crop. Each population occupied an area 1 ha in extent. The experimental fields were separated both from each other and other fields by a mouse-proof fence which prevented the animals from migrating. Constant observations were made in these populations of a number of ecological parameters, inter alia variations in numbers and the actual reproduction and mortality which took place.

Observations of these parameters were made by the $C M R$ method and for this purpose 140 wooden boxes, each containing 3 live-traps, with openings enabling the animals to enter were placed in each experimental field. From August 1971 to November 1972 the boxes were placed near the vole colonies, and from November 1972 to April 1973 were set out in a grid at even intervals of $9 \mathrm{~m}$. The voles were caught and removed for 2 days in each week, every 12 hours (4 inspections of the traps), and a record kept of the traping site, number of individual and sex, at the time of each capture.

The data collected, elaborated by the "Calendar of Captures « method (A ndrzejewski, 1969), provided information on variations in numbers, actual reproduction expressed as the percentage formed by individuals caught for the first time in their lives during a given month in relation to the population numbers in this month, and mortality i.e., the number of individuals which were caught for the last time in a given month, also expressed in percentage in relation to population numbers in this month. These parameters have been elaborated by Adamczewska-Andrzejewska \& Nabaglo (unpublished data).

In order to obtain information on the physiological state of the voles examined $5 \%$ of individuals, in relation to the current numbers of these animals, were caught every month from each population. The number of individuals examined was therefore different in different months. No material was collected during periods in which population numbers were very low (April, May, June 1972, February 1973). When dissection was carried out sex and state of gonads were determined, and the eye lens excised in order to define the individual's age. The animals' age 
was defined on the basis of eye lens weight (A d a m c ze wska-Andrzejewska, 1973), taking lens weight of $3.5 \mathrm{mg}$ as the criterion for dividing individuals into young and old. The alimentary tract was also excised for parasitological studies, and blood, kidneys, suprarenal glands, thyroid were taken for physiological studies.

Fat content was determined in the body of animals deprived of the abovementioned organs by extraction with paraffin ether using Puzanov and Badun's and Besson's method ( $\mathrm{Kra}$ u ze et al. 1966). For this purpose the voles were dried in an oven at $70^{\circ} \mathrm{C}$ to constant weight and kept in jars with ground glass stoppers. Before determining fat content the dried animals were minced in an electric mincer, then mixed mechanically in order to obtain material as homogeneous as possible. One sample about $1.5 \mathrm{~g}$ was taken from each individual and placed in an extraction dish of known weight. The sample together with the dish was dried once again at $70^{\circ} \mathrm{C}$ for 3 hours, then dried in an exsiccator over calcium

Table 1

Number of individuals examined in successive months.

\begin{tabular}{lrrr}
\hline Month, year & Females & Males & Total \\
\cline { 1 - 1 } August, 1971 & 24 & 12 & 36 \\
September, 1971 & 15 & 6 & 21 \\
October, 1971 & 21 & 8 & 29 \\
November, 1971 & 8 & 7 & 15 \\
December, 1971 & 6 & 8 & 14 \\
January, 1972 & 5 & 12 & 17 \\
February, 1972 & 7 & 13 & 20 \\
March, 1972 & 4 & 11 & 15 \\
July, 1972 & 36 & 16 & 52 \\
August, 1972 & 22 & 11 & 33 \\
September, 1972 & 31 & 20 & 51 \\
October, 1972 & 24 & 20 & 44 \\
November, 1972 & 20 & 37 & 57 \\
December, 1972 & 17 & 21 & 38 \\
January, 1973 & 9 & 11 & 20 \\
March, 1973 & 3 & 7 & 10 \\
April, 1973 & 4 & 2 & 6 \\
Total & 256 & 222 & 478 \\
\hline
\end{tabular}

carbonate for half an hour, then weighed on an analytical balance with accuracy at $0.0001 \mathrm{~g}$. Extraction lasted 3.5 to 4 hours from the time ether began to bubble. This time was sufficient for complete extraction of fat from the sample (M y r ch a, 1969). Fresh ether was used for each extraction. After completing extraction the dish together with the sample was dried in the same way as before extraction, then weighed. The weight of the fat extracted was calculated from the difference in weight of the sample before and after extraction. The ratio of weight of extracted fat to weight of the sample formed the $\%$ of fat content in dry mass of the animal. Any error involved in the method for determining fat content in the body of voles by extracting one sample from one individual did not exceed $13 \%$, if the number of individuals is not less than 16 during later analysis (B o c k \& $\mathrm{K}$ olod z i e j, 1973).

Variations in the fatness of the study population of voles were traced from 
August 1971 to April 1973, with the exception of April, May and June 1972 and February 1973. The results represent the average percentage of fat content in the dry mass of the body of groups of animals examined in successive months. In all 478 voles were examined in the above way (Table 1). In addition analysis was made of the fat content of 26 voles which died in live-traps in September 1971 and the results compared with data obtained for live animals.

\section{RESULTS}

Preliminary analysis of results was intended to check differences in the fatness of animals differing in respect of their ecological situation and physiological state.

Comparison by the $\chi^{2}$ method, on a level of significance $=0.05$ and 0.01 of the curve representing average fat content of all individuals from field $A$ with the analogical curve obtained for field $B$ did not reveal any statistically significant differences between them. Animals from the two fields were therefore combined in one group of voles for further analyses.

Table 2

Comparison of average fat content of pregnant and non-pregnant females in months with maximum reproduction.

\begin{tabular}{|c|c|c|c|c|}
\hline \multirow[b]{2}{*}{ Month, year } & \multicolumn{2}{|r|}{ Pregnant } & \multicolumn{2}{|r|}{ Non-pregnant } \\
\hline & $\mathrm{N}$ & $\begin{array}{l}\text { Avg. fat in dry } \\
\text { mass, } \%\end{array}$ & $\mathrm{~N}$ & $\begin{array}{l}\text { Avg. fat in dry } \\
\text { mass, } \%\end{array}$ \\
\hline August, 1971 & 11 & $17.4 \pm 0.9$ & 13 & $16.5 \pm 2.4$ \\
\hline July, 1972 & 20 & $18.8 \pm 0.7$ & 16 & $18.2 \pm 1.3$ \\
\hline August, 1972 & 12 & $22.9 \pm 1.5$ & 10 & $22.5 \pm 0.9$ \\
\hline Sept., 1972 & 14 & $20.9 \pm 1.4$ & 17 & $21.0 \pm 1.5$ \\
\hline
\end{tabular}

A check was next made to see whether there is a difference in fat content between pregnant and non-pregnant females. Females examined in months of maximum reproduction were used (August 1971, July, August, September 1972) in order to ensure of pregnant and non-pregnant females from the series of animals captures in a given month was statistically uniform (Table 2), which permitted of treating these two groups of females jointly in further analyses.

A statistically significant difference (Student's $t$ test) was, however, found in the average body fat content of females and males of $M$. arvalis in July, August and October 1972. Although the fatness of these groups did not differ to a statistically significant degree in the other months of the whole study period, the course taken by the curves of average fatness of females and males was slightly different in different months (Fig. 1).

The fatness of animals of both sexes exhibited seasonal variations 
during the study years. The increase in fat content of bank voles from October 1971 to February 1972 (males) and March 1972 (females) and from October 1972 to January 1973 was statistically significant. Reduction in fat content in the body of males by $3.3 \%$ of fat in the dry mass from February to March 1972 was also statistically significant. The following year decrease in the fatness of animals of both sexes was observed chiefly during the period from March to April 1973, the average reduction of fat content being $5 \%$ in dry mass in the case of females and $9 \%$ in the case of males. The differences were not, however, statistically significant, probably on account of the small numbers of animals examined (Fig. 1).

In general the fatness of females during the period 1971/2 was slightly lower than that of males, but this difference was not statistically significant. In the following study year, however, fat content in females was on an average $3.2 \%$ higher than in males, except for October and November 1972, where fat content of females falls from a maximum of $22.7 \pm 1.1 \%$ in August to a minimum of $15.9 \% \pm 1.3 \%$ in October. In spring i. e., in March 1972, and in March and April 1973 males had on an average $5 \%$ less fat than females (Fig. 1).

Comparison by means of Tukey's test of the average fat content in the body of females and males separately in the same successive months showed that the fatness of all the animals examined in 1972/3 was significantly higher than for 1971/2. From August-March (except for February) this difference was on an average $4.9 \%$ for females and for males $3.7 \%$ of fat in dry mass.

Further analysis of results was made for the purpose of tracing variations in the fatness of vole populations in different years and seasons of the year in relation to such ecological parameters as dynamics of numbers, reproduction and mortality.

It is clear from the unpublished date of Adamczewska-Andrzejewska \& Nabagło that numbers of the study population were $50 \%$ lower in 1971 than in 1972. The actual reproduction in August, September and October 1971 expressed in the number of newly-marked individuals was over $20 \%$ lower than in the analogical months of 1972 (Fig. 1). As the number of young individuals (newly-marked) in the population in 1971 became gradually smaller from August 1971 (51.7\% of newly-marked individuals) up to January 1972 (4.4\% of newly-marked individuals), but in the following study year this process was more abrupt and lasted for a shorter time, from August 1972 (68.7\% of newly-marked individuals) to November 1972 (12.5\% of newly-marked individuals), it would appear that reproduction was more intensive in 1972 (Fig. 1). Intensity 
of mortality among the animals in the population in $1972 / 3$ was also on an average $20 \%$ higher than in $1971 / 72$ (Fig. 1).

Thus both the fatness of the animals and population numbers and also actual reproduction and mortality were higher in 1972/3 than in 1971/2.
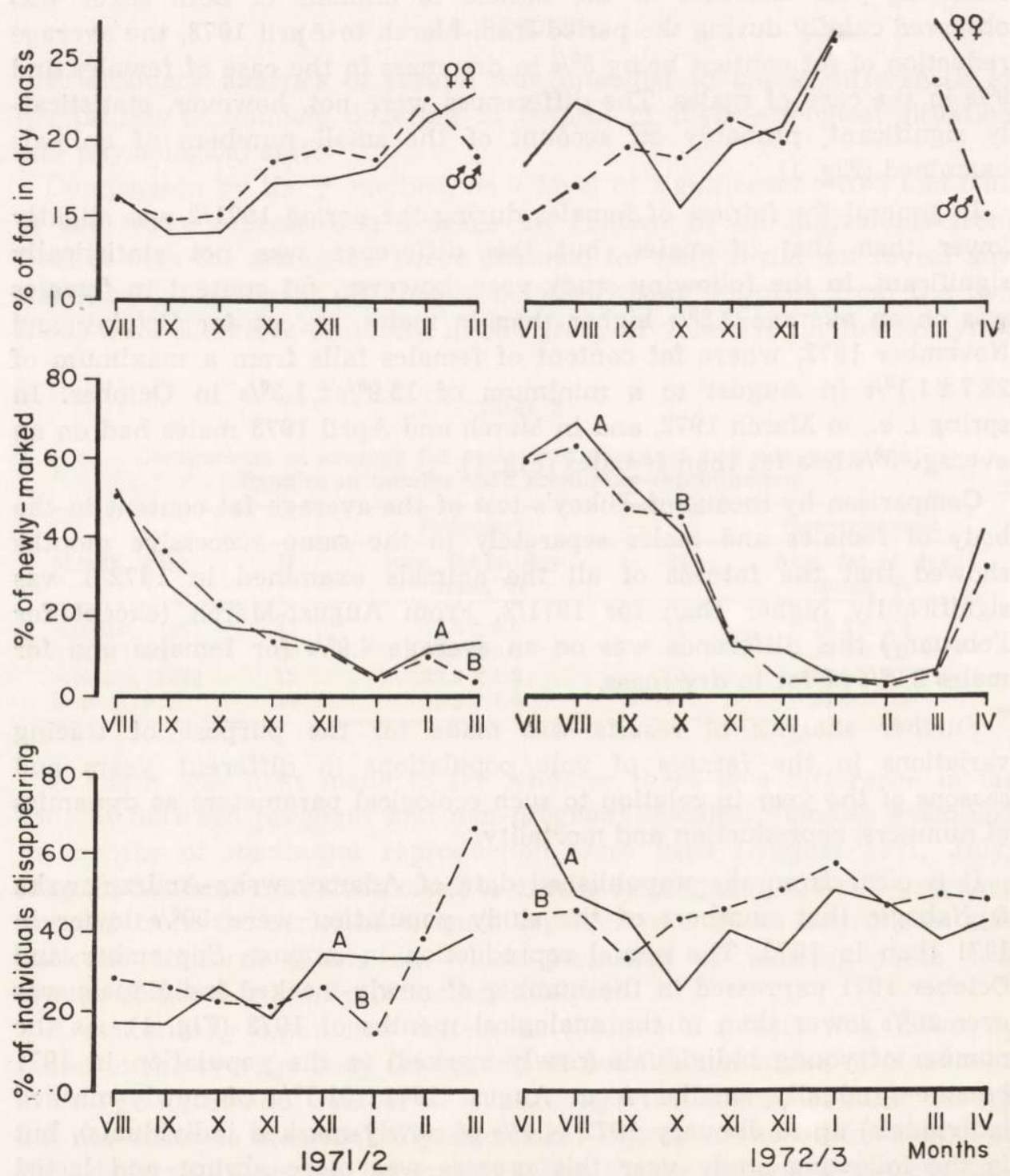

Fig. 1. Seasonal changes in average fat content of females and males in relation to variations in intensity of actual reproduction and mortality in the vole population. A - animals from field $A$ (females and males); B - animals from field $B$ (females and males) 
In searching for the causes of seasonal variations in fat content in the body of animals in the study population, comparison was made of the degree of fatness of females and males in successive months with the actual reproduction and mortality which took place (Fig. 1). In the study years the increase in fatness of the population in autumn and winter (October, November, December, January, February) coincided with the end of the actual autumn reproduction which accurred during September-November, while decrease in fatness in spring (March, Aprii) coincided with the start of the spring reproduction period. These phenomena were clearly manifested in studies on the population from July 1972 to April 1973, despite the fact that the lack of material from February 1973 made it impossible to define fat content in the population in this month. It may be that earlier reduction in average fat content in the body of males in March 1972 and March 1973 in comparison with the average fat content of females was due to the fact that they reach

Table 3

Comparison of average fat content of individuals surviving and dying in live-traps in September 1971.

\begin{tabular}{lrcrrc}
\hline & \multicolumn{2}{c}{ Surviving } & & \multicolumn{2}{c}{ Dying } \\
\cline { 2 - 3 } \cline { 5 - 6 } & N & Avg. fat in dry mass, \% & & Nvg. fat & in dry mass, \% \\
\hline Females & 15 & $14.0 \pm 1.1$ & & 11 & $11.0 \pm 1.2$ \\
Males & 6 & $15.0 \pm 0.9$ & & 15 & $11.0 \pm 1.1$ \\
Young $^{1}$ & 3 & $13.0 \pm 0.9$ & & 17 & $12.0 \pm 1.0$ \\
Old $^{1}$ & 18 & $14.0 \pm 1.0$ & 9 & $8.0 \pm 0.4$ \\
\hline
\end{tabular}

1 Females and males together

the stage of ability to take part in reproduction earlier (Fig. 1). No relation was, however, observed between seasonal variations in fat content and intensification of mortality expressed in the percentage of individuals disappearing from the population (Fig. 1).

As cases occurred during the experiments of animals dying in live traps, examination was made to find out if these animals differed in respect of fat content from the live animals caught in the same month. The analysis made shows that the average fat content of females and males surviving in traps in September 1971 was greater by $3-4 \%$ of fat in dry body mass than the fat content of the dead individuals (Table 3). Statistically significant differences (Student's $t$ test) in the fat content of the two groups were found among old individuals (the difference was $6 \%$ of fat per dry body mass), but no differences were observed between young individuals (Table 3 ). It would seem that animals with low fat content die more rapidly under the stress conditions formed by 
their being caught in live traps (Andrzejewski \& Wroclawek, 1961; P l a t t, 1968). The information obtained during dissection on the state of the gonads in surviving and dead individuals shows that all old individuals (both living and dead) were sexually mature and had taken part in reproduction during this period, while young (living and dead) had not. It would seem that reproduction may be correlated with reduced fat content in the body of certain old individuals and hasten their death under stress conditions, whereas some other factors not causing decrease in body fat content must have affected the mortality of young animals caught in traps during this time.

\section{DISCUSSION}

Fat occurs in an organism as a subcutaneous fat, internal fat, termed intestinal, and fundamental fat, that is, the fat contained in different organs ( $\mathrm{F}$ e d y k, 1970), and consequently when determining the absolute fat content in a body the whole of the animal must be submitted to extraction. Although this condition has not been met in the present studies, it would appear that the fat content defined here is comparable when describing its variations in time and between different groups of animals. The error involved in the method used depends to a great extent on the degree to which the material originating from one individual is mixed. This error has been reduced in our case by calculating the average fat content for groups of animals (B o c k \& K o łodzi e j, 1973), and therefore it is not the absolute fat content, which has been examined, but the average fat content for the groups of voles studied. It would consequently appear that the calculated index of fat content, although not illustrating the full fat content in an organism, can be accepted as describing variations taking place in the populations of voles examined.

It can be seen from material presented in this paper that: (1) fat content of the study populations of bank voles differs in successive study years, (2) fat content of the animals increases in autumn and winter, and decreases in early spring, (3) fat content varies in the same way as numbers, reproduction and mortality over a two-year cycle, and is correlated with the intensity of reproduction in one-year cycle, (4) fat contents can be treated as an indictor of condition, particularly in the case of animals dying in live-traps. It would seem that condition determined by the fat content in the body concur with certain ecological parameters of the population variations in numbers, actual reproduction and mortality taking place. The degree of fatness may therefore constitute an indicator of population processes. Since fluctuations in the 
numbers of these animals take place over a cycle of several years, seasonal variations in the fat content of their bodies may certainly also have a slightly different character in successive study years. Such phenomena have also been observed by $\mathrm{S}$ a w icka-Ka pusta (1968), in Apodemus flavicollis (Melchior, 1834) and Pucek (1973) in Clethrionomys glareolus ( $\mathrm{S} \mathrm{chreber}, 1780$ ) and $A$. flavicollis. The increase in fat content found in the study population of bank voles in autumn and winter, and decrease in spring, is also characteristic of other species of animals. Similar seasonal changes in fat content have been observed in A. flavicollis by Sawicka-Ka pust a (1968) and also by My r cha (1969) in certain members of Soricidae, and by H a y w a d (1965) in six geographical races of Peromyscus. P u c e k (1973), however, in C. glareolus did not find any cycle of seasonal changes in fat content which tended in one particular direction. In the opinion of many authors different factors affect seasonal dynamics of variations in the body fat content of small rodents: habitat temperature (S e a la nder, 1951), habitat temperature and food resources (S e a l a n d e r, 1955), food resources of the habitat (Connel after Golley, 1962); the animals' physiological state and age ( $\mathrm{J}$ a m e s on \& M e a d, 1964), changes in the degree of population density (H sia-W u-ping \& Sun-Chung-lu, 1963), individual and geographical variations ( $\mathrm{H}$ a y w a r d, 1965).

The average fatness of animals may differ during the same seasons of the year in different species, e. $g .:$ in winter the figure was $26 \pm 1.2 \%$ in the bank vole population, $20.8 \pm 5 \%$ for A. flavicollis during the same period (Sawicka-Kapusta, 1968) and $24 \pm 1.5 \%$ for C. glareolus (Andrzejewski, 1975).

In previous discussion it was found that condition defined by fat content in an animal's body may coincide with the ecological indexes of the study population of bank voles and be currently characteristic of the population. Can it also be used as an index for forecasting the development of this population?

Two possibilities must be taken into consideration in the first place: fat deposited in autumn forms stored material in the voles' body to be used during winter. It follows from this that the greater the fat content of a population in autumn, the greater the grounds for expecting that the resistance of the animals to habitat factors and their viability will be higher. The relation between numbers in spring and degree of fat content in the population in autumn of the previous year would be in direct proportion. In the second place fat deposited in autumn is only an index of the animals' physiological state, and the relations between it and variations in numbers are of a very complex character.

The studies made show that a low fat content for the population in 
the autumn of 1971 (Fig. 1) gave relatively large numbers of animals in the spring 1972, and in turn higher fat content in the population in autumn and winter 1972 (Fig. 1) gave total numbers of animals $50 \%$ lower than in the preceding year, i. e., 25 individuals/ha in population $A$ and 10 individuals/ha in population $B$. Differences in the fat content of individuals from field $A$ and field $B$ were not statistically significant. It would therefore appear that the population numbers of bank voles in spring do not depend in direct proportion on the amount of fat deposited in autumn and winter.

These are animals with a high metabolic rate (Trojan \& Wojciechowska, 1969), accumulating too small an amount of fat in autumn to meet the increase in their energy requirements during winter. The highest fat content in the study population was observed at the end of winter 1972 , when it was about $27 \pm 1.2 \%$ fat per dry body mass, which forms only about 2 grammes of fat per individual, that is, $18 \mathrm{kcal}$. This amount is sufficient only to cover maintenance costs for not quite 2 days. Fat deposited in autumn cannot form the energy supply for the voles' thermoregulation. Subcutaneous fat may, however, form thermal insulation. The degree of fatness may also point to the animal's current condition and be an indicator of the physiological state at a given moment. The results discussed above on the correlation of fat content with current numbers and natality, and also with the death of these animals in live traps, argue in favour of this.

Acknowledgments: I am greatly indebted to Dr. hab. R. Andrzejewski for his supervision and helpful comments during the preparation of this paper, and must also thank Dr. K. Andrzejewska and L. Nabaglo, M. Sc. for giving me access to data, so far unpublished, on ecological parameters: dynamics of numbers, and actual reproduction and mortality of the study population. My grateful thanks are also due to Dr. hab. A. M y r ch a for consultations.

\section{REFERENCES}

1. Adamczewska-Andrzejewska K., 1973: The lens weight as indicator of age in the wild Microtus arvalis population. Bull. Acad. Polon. Sci., Cl. II, 21: $331-336$.

2. Andrzejewski R., 1969: Analiza wyników połowów drabnych ssaków metodą „Kalendarza Zlowień”. Zeszyty Naukowe Inst. Ekol. PAN, 2: 1-104.

3. Andrzejewski R. \& Wroclawek H., 1961: Mortality of small rodents in traps as an indications of the diminished resistance of the migrating part of a population. Bull. Acad. Pol. Sci. Cl. II., 9, 12: 491-492.

4. Andrzejewski R., 1975: Supplementary food and the winter dynamics of bank vole populations. Acta. theriol., 20, 2: 23-40.

5. Bock E. \& Kolodziej A., 1973: Estimation of fatness of common vole by the metod of collective sample. Acta. theriol., 18, 10: 201-207.

6. Czaja-Topińska J., 1969: Migration dynamics and changes in fat deposition in the Great Tit, Parus major L. Acta ornithol. 11, 10: 357-378. 
7. Dolnik V. R., 1960: Mechanism energetičeskoj podgotovki ptic $k$ pereletu i faktory ee opredeljajuščie. Tez. Dokl. IV Pribalt. orn. Konf. Riga: 29-30.

8. Dolnik V. R., 1963: Fizjologičeskie osnovy migracii ptic. Mater. Konf. po složnym Formam Povedenija Životnych: 120-121, Leningrad.

9. Doln ik V. R., \& Bljumental T. I., 1964: Bioenergetika migracii ptic. Usp. sovr. Biol., 58: 280-301.

10. F e d y k A., 1970: Badanie podstawowych składników ciała ssaków. Wiad. ekol., 16, 2: $168-178$.

11. Golley F. B., 1962: Mammals of Georgia. A study of their distribution and functional role in the ecosystem. Univ. Georgia Press: 1-218. Athens.

12. H a y ward J. S., 1965: The gross body composition of six geographic races. of Peromyscus. Canad. J. Zool., 43: 297-308.

13. Hsia-Wu-ping \& Sung-Chung-lu, 1963: On the relative fatness of the red-backed vole, Clethrionomys rutilus Pall. Acta zool. Sinica, 15: 33-43.

14. Jameson E. W. Jr. \& M e ad R. A., 1964: Seasonal changes in body fat, water and basic weight in Citellus lateralis, Eutamias speciosus and E. amoenus. J. Mammal., 45: 359-365.

15. Krauze S., Bożyk Z. \& Piekarski L., 1966: Podręcznik laboratoryjny analityka żywnościowego. Państw. Zakł. Wyd. Lek.: 1-588. Warszawa.

16. Krybill H. F., Bitter H. L. \& Hankins O. G., 1962: Body composition of cattle. II. Determination of fat and water content from measurement of body specific gravity. J. appl. Physiol., 4: 575-578.

17. Myrcha A., 1969: Seasonal changes in caloric value, body water and fat in some shrews. Acta theriol., 14, 16: 211-227.

18. Newton J. \& Evans P. R., 1966: Weights of birds in winter. Bird Study, 13: $96-98$.

19. Odum E. P. \& Connel C. E., 1956: Lipid levels in migrating birds. Science, 123: $892-894$.

20. Odum E. P. \& Perkins on J. D. Jr., 1951: Relation of lipid metabolism to migration in birds: seasonal variations in body lipids of the migratory whitethroated sparrow. Physiol. Zool., 24: 216-230.

21. Pearson A. M., 1963: Implications of research on body composition for animal biology: an introductory statement [In: "Body composition ", Eds. Whipple, H. E. Siverzweig S., Brožek J.]. Ann. N. Y. Acad. Soi., 110: 290-301.

22. Platt A. P., 1968: Differential trap mortality as a measure of stress during: times of population increase and decrease. J. Mammal., 49, 2: 331-335.

23. Pucek M., 1973: Variability of fat and water content in two rodent species. Acta theriol., 18, 6: $57-80$.

24. Sawicka-Kapusta K., 1968: Annual fat cycle of field mice, Apodemus: flavicollis (M e lch ior, 1834). Acta theriol., 13: 329-339.

25. Sealander J. A. Jr., 1951: Survival of Peromyscus in relation to environmental temperature and acclimation at high and low temperatures. Amer. Mild. Natur., 46: 257-311.

26. Sealander J. A. Jr. \& Walker B. Q. Jr., 1955: A study of the cotton rat. in Northwestern Arkansas. Proc. Arkansas Acad. Sci., 8: 153-162.

27. Trojan P. \& Wojciechowska B., 1969: Ecological model and tables of the daily costs of maintenance (DEB) of Microtus arvalis (Pall.), Ekol. pol. A, 17, 17: 313-342.

Accepted, October 20, 1975. 
Anna KOEODZIEJ-BANACH

\section{ZMIANY OTEUSZCZENIA EKSPERYMENTALNEJ POPULACJI NORNIKA ZWYCZAJNEGO}

\section{Streszczenie}

Badano otłuszczenie populacji nornika, Microtus arvalis ( $\mathrm{P}$ a 11 a s, 1779) jesienią, zimą i wiosną $w$ dwóch kolejnych latach. Dwie populacje (A i B) żyły na uprawie lucerny, izolowane były od siebie i innych upraw szczelnym ogrodzeniem. Otłuszczenie norników porównywano z niektórymi wskaźnikami ekologicznymi (dynamiką liczebności, zrealizowanym rozrodem i śmiertelnością), które były równolegle śledzone. Stwierdzono, że w 1972 r. otłuszczenie norników było wyższe niż w roku poprzednim (Fig. 1). Jednocześnie liczebność populacji (A d a m c ze w s k a-Andrzejewska \& $\mathrm{Nabaglo,} \mathrm{w} \mathrm{przyg.),} \mathrm{zrealizowany} \mathrm{rozród} \mathrm{i} \mathrm{śmiertel-}$ ność były wyższe w roku 1972 w porównaniu z rokiem 1971 (Fig. 1). Jesienią i zimą otłuszczenie nieznacznde wzrastało, a wczesną wiosną malało zarówno u samic jak i u samców w obu badanych latach (Fig. 1). Wzrost otłuszczenia norników jesienią i zimą zbiegał się z końcem rozrodu jesiennego, natomiast spadek otłuszczenia wiosną $-z$ rozpoczęciem rozrodu wiosennego (Fig. 1). Nie wykazano zależności między nasileniem śmiertelności, a zmianami w otłuszczeniu norników (Fig. 1). Osobniki, które padają w pułapkach (szczególnie starszych klas wieku) posiadają niższą zawartość tłuszczu w ciele w porównanu ze zwierzętami odłowionymi we wrześniu $1971 \mathrm{r}$. (Tab. 3). Porównanie średniego otłuszczenia populacji $A$ i $B$ w roku 1971 i 72 nie wykazało różnic istotnych statystycznie, natomiast liczebność populacji $A$ w 1973 r. była dwukrotnie wyższa niż liczebność populacji na polu $B$. Kondycja określana zawartością tłuszczu w ciele wydaje się być zbieżna ze wskaźnikami ekologicznymi populacji: dynamiką liczebności, zrealizowaną rozrodczością i śmiertelnością w cyklu dwuletnim oraz zrealizowaną rozrodczością w cyklu rocznym i charakteryzuje ją aktualnie. Nie wydaje się natomiast by ta kondycja mogła być dobrym wskaźnikiem do prognozowania rozwoju populacji. 